\title{
Bursa Of Fabricius
}

National Cancer Institute

\section{Source}

National Cancer Institute. Bursa Of Fabricius. NCI Thesaurus. Code C111141.

An epithelial outg rowth of lymphoid tissue in the cloaca of young birds, responsible for Blymphocyte maturation. It undergoes atrophy and involution at six months of age. 